\title{
Problem of Translating Metaphoric Expressions in the Holy Qur'an in to English
}

\author{
Dr. Abdelrazig Abdelghani Mahil Ibrahim \\ ESP Lecturer - Posha Academy - Kingdom of Saudi Arabia \\ *Corresponding Author: Dr. Abdelrazig A bdelghani Mahil Ibrahim, ESP Lecturer - Posha Academy- \\ Kingdom of Saudi Arabia
}

\begin{abstract}
The scope of this study was in the field of applied linguistics. The aim of this study is to assess how metaphoric expressions are translated in the Holly Qur'an and to investigate challenges facing translators in translating the metaphoric expressions in the Holly Qur'an. The researcher chose two English translations of the $H Q$, the first is the translation of the meaning of the $H Q$ in the English Language by Grand Shaykh, Professor Hassan Qaribullah \& Shsykh, Ahmed Darwish and the second one is the English translations of the $H Q$ by Dr.Muhammad Muhsin Khan \&Dr. Muhammad Tagi-ud-Din Al-Hilali. The researcher selected (5) Holly Verses metaphors to be analyzed and investigated. Metaphor types were categorized by an assessment of the two translations followed by a discussion between the two versions of translation.
\end{abstract}

Keywords: Holly Qur'an, Holly Verses, metaphor, metaphor expressions.

\section{INTRODUCTION}

The main goal of translation is to convey the message of the ST through providing equivalent units between the SL and TL. Achieving this aim is not an easy task and it poses many difficulties and problems, the degree of difficulty rises when dealing with rendering metaphors from one language into another since the translation of metaphor is considered as the most particular problem in translation. Metaphor is considered as the most important form of figurative language use. It is used to describe something in terms of another. It is literary device where a comparison is made between two subjects. The Holy Qur'an (HQ) is so rich with figurative language use especially metaphors, translating the metaphors of the Holy Qur'an is a hard task and poses great challenges for translators. Thus, translators usually attempt to adopt certain techniques and procedures in order to render the metaphoric expression from the SL into the TL successfully.

A long with the development of the translation science, metaphor poses serious challenges for standard theories of meaning, because it seems to straddle many important boundaries .Newmark (1989, p104) stated that metaphor is difficult problem in the world of translation; he stressed the difficulties because the metaphor covers all figurative language use.

One of the messages which need to have the right understanding is the Holly Qur'an. It is the final divine revelation provides mankind guidelines in every part of life. However, the majority of Muslims in the world are non-Arabic speakers which indeed make it a necessity to deal with the Holly Qur'an in various languages .The English Language specially, as the world's major international language would make a good medium for understanding the Holly Qur'an and thereby helping Muslims spread peace and harmony all over the world.

Richard (2005,p.8) states that he message of the Holy Qur'an sometimes is stated explicitly but sometimes implicitly buy using figurative language .The most figurative language that occurs in the Holy Qur'an is metaphor. Modern Muslim scholars gather there are more than four hundred metaphoric words in the Holly Qur'an, although many of these words are become common word.

\section{TyPes OF Figurative LANGUAGE}

The figurative language comes in several categories; it includes diversity of images and literary devices such as metaphors, similes, irony, metonymies, synecdoche, personification, and allegory. 


\subsection{Metonymy}

Crystal in his Encyclopedic Dictionary of language and languages (1992) states that:

Metonymy is figure of speech in which the name of an attribute of an entity is used in place of an entity itself. People are using metonymy when they talk about the bottle to mean 'drinking' or the press to mean 'newspapers' (p. 250).

It is the use of a part to represent a whole, or the use of one item to stand for another with which it has become associated.

For example: 'The Algerian Foreign Office has announced' for (the Algerian Foreign

Secretary has announced).

( صرحت وزارة الخارجية ) ( صرح وزير الخارجية ).

\subsection{Similes}

Simile is another figure of speech described by the Cambridge Advanced Learner's

Dictionary as "the use of an expression comparing one thing with another, always including the words as or like" (Walter, 2008).

Consider some examples of similes in both languages: the English and the Arabic language:

( الناس كأسنان المشط في الاستواء )

1-"People are like the teeth of a comb in equality".

2."Tall as a mountain".

$$
\text { (طويل كالجبل) }
$$

\subsection{Metaphor}

Metaphor has been considered as the most important form of figurative language use. This term derives from the Greek word "metapherein" (meta refers to 'over' and pherein to 'bear' or to 'carry') and means "the carrying of meaning of one word over to another word". The Oxford Word power Dictionary (2006, p. 489) describes metaphor as: "A way of describing something by comparing it to something else which has the same qualities (but without using the words 'as' or 'like'.

Other definition of metaphor refers to Peter Newmark (1988, p. 104) who defines metaphor as: "describing something in terms of another".

Newark states that metaphor may be single (one word) or extended (a collocation, a sentence, a proverb, a complete imaginative text).

Furthermore, Gillian Lazar (2003,p.1) explains that metaphor involves "a carrying across of meaning from one object to another and identification is made between two apparently dissimilar things, so that some of the characteristics of the one are carried over to the other".

Based on above definitions from various sources, we can draw the following conclusion that metaphor is defined in more or less as applying one thing in the name of another. Consider this example of metaphors in English: 'Peter is a lion' is metaphor which indicates that the person "peter" is as powerful and brave as the animal "lion".

Al-Zoubi et al (2006) state that translating metaphor is a difficult practical process that translators face while translating metaphor from English into Arabic. A metaphor is sometimes confused with a simile especially for translators who may translate metaphor into simile or vice versa. However, it is not too difficult to decide the case of simile because of the correlative existence of the simile markers like "as, similar to and like" which are not found in metaphor. Simile is usually used to make a picture more emphatic or vivid, e.g. "he is as cowardly as a hen", " she is like a rose" and" it is as white as snow". Thus, a simile can be defined as a figure of speech in which two essentially unlike things are compared to each other in at least one feature, using words such as "like", "as", or "similar to". For example, his heart is as hard as a rock, her face like the sun. 
Many traditions and customs in Arab culture are quite different from those in the west, but both languages use metaphors in such a way that confirms universal conventional images and attitudes, and so generate similar metaphors. Indeed, such metaphors are the summary of the same human experiences in various cultures.

Regarding Holy Quran (HQ), it is considered the most rhetorical holy book; it is a challenge for the whole world. Allah sent His HQ to His Messenger with an Arabic tongue, it is full of rhetorical styles that cannot be compared to any holy scripture as Allah said in the second Surah (Al-Baqrah), verse (23):

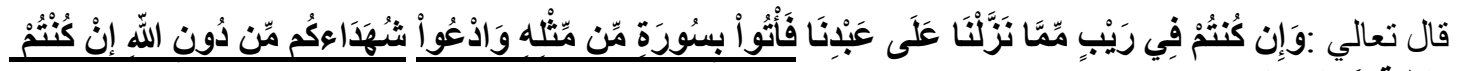

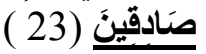

That translated as: produce a surah of the like thereof and call your witnesses besides Allah, if you are truthful.

\section{Statement of the Problem}

One of the most crucial problems in translation is the problem of translating metaphoric expression in the Holly Qur'an (HQ) verses. Most of the previous studies focused on translating metaphor within business, economic and other. Similarly, the translations of the HQ were discussed and analyzed by different translators, but studies about translating metaphor in the HQ is insufficient and less discussed. The aim of this study is to investigate how Arabic / English translators translate the expressions of the (HQ) verses. Essentially, the researcher found that it is important to investigate the translation of metaphorical expressions in the HQ, from Arabic into English. In this regard the present study may shed light on the significance of metaphor in the HQ.

\section{SigNIFICANCE OF THE STUDY}

The study is considered very significant because its results are expected to have the following benefits:

1. The results will show the clear description about metaphor translation in English translation of the HQ.

2. The study will add some literary insight in translating metaphor, especially in translating the HQ.

3. The results will be used by other researchers as one of the references can be referred to.

4. This study will improve the readers' knowledge of understanding metaphor and its meaning in English translation of the HQ.

\section{OBJECTIVES OF THE STUDY}

This study has the following objectives:

1. To know the English translation of metaphors in the HQ.

2. To compare two translations for metaphoric expressions in the HQ.

3. To explore how the translator renders metaphors in general and metaphors of the HQ in particular into the target language.

\section{QUESTIONS OF THE STUDY}

The current study is set to answer the following questions:

1. To what extent do the two translations of the HQ can give the accurate meaning of the Arabic metaphoric expression?

2. What are the methods that were followed in translating the metaphoric expression?

\section{LiMitations OF THE STUDY}

1. This study is limited to translation of the Holy Qur'an in general and translation of the metaphoric expressions in the Holy Qur'an particularly.

2. This study is also limited in analyzing and comparing the translation of metaphoric expressions in (5) verses of the HQ verses to two translations. The first translation is by Grand Shaykh, Professor 
Hassan Qaribullah \& Shaykh, Ahmed Darwish and the second one is by Dr.Muhammad Muhsin Khan \&Dr. Muhammad Tagi-ud-Din Al-Hilali

\section{Methodology of The Study:}

\subsection{The Sample of the Study}

The researcher is going to choose two English translations of the HQ, the first is the translation of the meaning of the HQ in the English Language by Grand Shaykh, Professor Hassan Qaribullah \& Shsykh, Ahmed Darwish and the second one is the English translations of the HQ by Dr.Muhammad Muhsin Khan \&Dr. Muhammad Tagi-ud-Din Al-Hilali.

The sample of this study is (5) verses in the HQ with their English translations were chosen to be compared and analyzed.

\subsection{Data Collection}

In this study, data will be collected from various verses of the HQ. In this context, the study will not take the whole metaphors in the HQ. The study will choose (5) metaphoric expressions from the Arabic version of the HQ. The (5) Qur'anic verses are going to be shown to a jury from the English language Departments at some universities in Khartoum State who are professional in English-Arabic translation so as to be validated. They were asked to write their comments in detail and their comments and suggestions are going to be taken into consideration, followed by setting up the final version of the (5) verses .

\subsection{Methods to Analyze the Verses}

The researcher is going to divide the process of analyzing the translation of metaphoric expressions into three different steps:

1. Identifying the metaphoric expression in the HQ verse. The metaphoric expression will be present in Arabic language.

2. The translators' translation to the metaphor in the verse.

3. Comparing the two translations taking into consideration, the original meaning of the metaphor, the suitable words and expressions used in translating the metaphoric expression, the strong rhetorical in the translated verse, and its relation in interpretation books

4. Assessing the whole translations in sum.

\section{DISCUSSION}

To answer the question of this study, the researcher is going to analyze the Arabic Holy Qur'anic verses and their translations as follows:

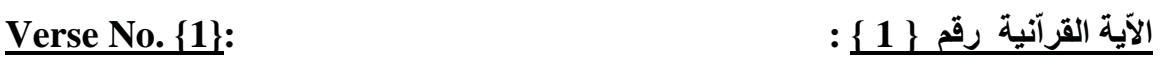

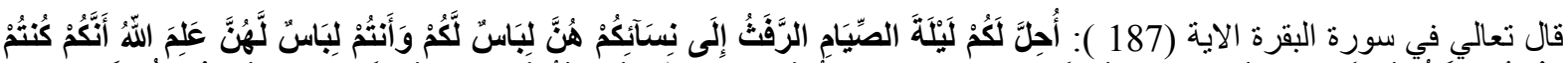

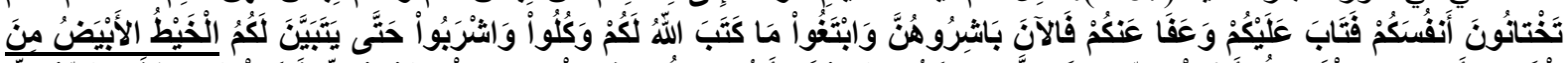

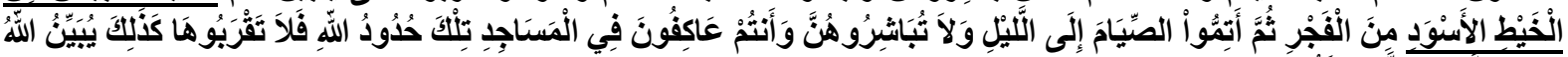

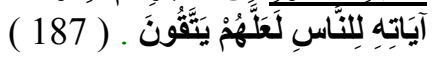

The metaphoric expression is

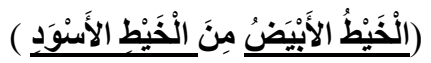

The first translators translated the metaphoric expression as: Eat and drink until the white thread becomes clear to you from a black thread at the dawn

The second translators translated it as: and eat and drink until the white thread (light) of dawn appears to you distinct from the black thread (darkness of night) at dawn. The two metaphoric expressions were translated literary by both translators, but the second translators explained the meaning of these metaphoric expressions between brackets . They

النهار indicated light

This can make a problem to the English reader because he is not going to understand the meaning of the metaphoric expression. 
Verse No. $\{2\}:$

الآية القرآنية رقم \{2\}

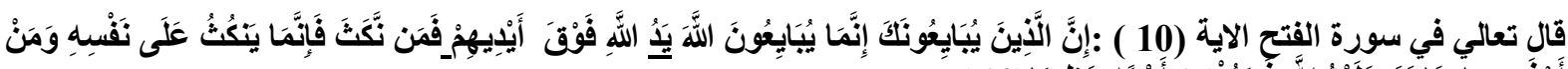

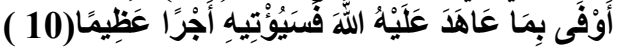

The metaphoric expression is (يُّ) . The intension of the verse aims to show the power and control of Allah to Muhammad. The metaphoric expression is translated by Shaykh Hassan Qaribullah \& Shaykh, Ahmed Darwish into (the hand of Allah). The second translators also translated it as (the hand of Allah), however this translation will show a problem if English language doesn't have the same usage as the source language.

Verse No. $\{3\}$ :

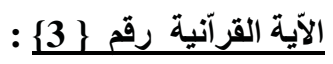

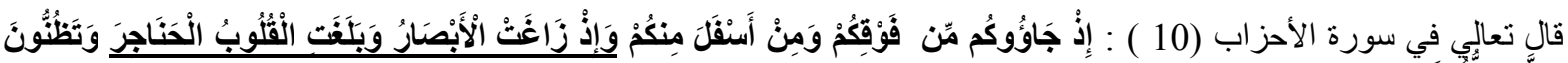

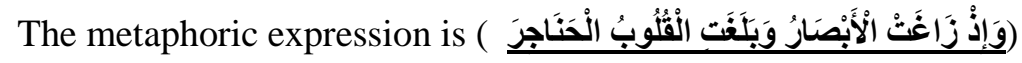

The first translators Hassan and Ahmed translated it as: They came on you from above and from below, and when your eyes swerved and your hearts leapt to your throats, and you thought thoughts about Allah

The above Arabic metaphoric expression was translated into English by the second translators Muhammad Khan and Muhammad Hilali translated as: the eyes grew wild and the hearts reached to the throats. That means in Arabic : ازدات حيرة العيون و القلوب بلغت الحناجر

Verse No. $\{4\}$ :

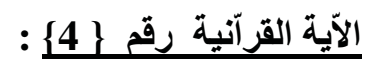

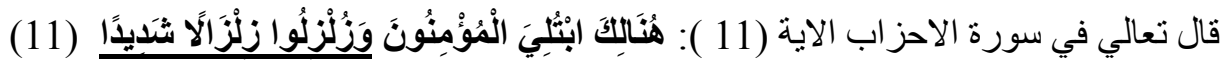

The metaphoric expression is

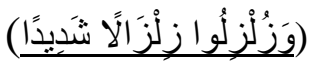

The first translators translated it the Arabic metaphoric expression as: There the believers were tried, they were shaken, a severe quake. The second translators translated it as: There the believers were tried, and shake with a mighty shaking.The English translation of the two translators meet the Arabic interpretation in (Al- qortobi) as: ).(هنزو ا من شدة الخوف)

The SL metaphoric expression was translated into a TL metaphoric expression .Both of them have a similar rendering in English.

Verse No. \{5\}:

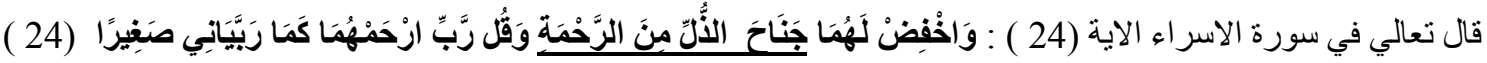

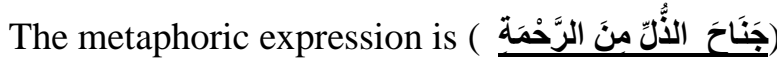

The first translators translated the Arabic metaphoric expression as:

And lower to them the wing of humbleness out of mercy and say: 'My Lord, be merciful to them, as they raised me since I was little. '

The second translators translated it as: And lower to them the wing of submission and humility through mercy, and say: 'My Lord! Bestow on them your mercy as they did bring me up when I was young."

The Arabic metaphoric expression here is embedded in the wing of the wing is used in Arabic as a metaphor in many جناح الطائر the bird

Expressions just as in English Language .The far meaning here is evidence in obeying our parents and be humble with them, saying nothing to annoy them. Their rendering meet the Arabic interpretation in (Al-qortobi)

$$
\text { (ألن جناحك الذليل من الرحمة لرقتلك عليهما). }
$$

\section{FindingS AND CONCLUSION}

From the previous analysis that related to translating the different metaphoric expressions of the Holy Qur'an from the Arabic language into English, we can notice that the translators adopted different techniques and procedures aiming at reproducing the real meaning of these expressions to the target readers. Also, and since translating the metaphor in general and the metaphor of the Holy Qur'an in 
particular face many difficulties and obstacles, the translators in some samples failed in reproducing the same image and effect of the original metaphor to the target text and they rendered these metaphors literally without reproduce the intended meaning behind these metaphoric expressions.

The comparative analysis of the metaphoric expressions that exist in the Holly Qur'an which mentioned above with their English translation reveals that translating metaphor of the Holy Qur'an is not an easy task and it raises many challenges for the translators. This due to the different difficulties that arise from translating the religious texts on the one hand. And the multiple problems within translating the metaphoric expressions from one language into another on the other hand.

The process of translating the metaphor in general and the metaphor of the Holy Qur'an in particular requires a translator who is fully competent with both the Arabic and English rhetoric, the translator should be also have an adequate knowledge and experience of certain subjects that related to the Islamic religion in general and the Holy Qur'an in particular, besides to the well knowledge of both cultures in order to render the same effect and meaning of the source language metaphor successfully to the target readers.

\section{REFERENCES}

[1] Al Zoubi. M, Al Ali. M, \&Al Husanawi. A. (2006). Cogon-Cultural issues in translating metaphor. Perspectives-studies in translatology. In Arab World English Journal (AWEJ). (No.4, pp.295-306, 5015). Retrieved from:http://awej.org/images/AllIssues/Specialissues/Translation4/19.pdf

[2] Lazar, G. (2003). Meaning and Metaphor. Cambridge: Cambridge University press.

[3] Newmark, P. (1988). A Text book of Translation. New York: Exter Prentice- Hall.

[4] Oxford Word power Dictionary -2nd Edition. (2006). Oxford: Oxford University Press.

[5] Bell, R. (2005).Introduction to the Qur'an. Edinburgh University Press.

\section{AUTHOR's BIOGRAPHY}

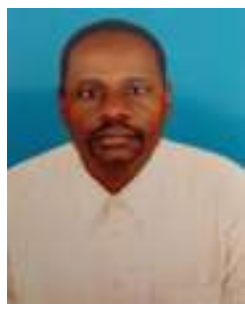

Dr. Abdelrazig Abdelgani Mahil, got his Ph.D. in English Language from Alzaiem Alazhari University in (2017). He has an M.A in General Translation from University of Juba (2010) He also got a Post graduate Diploma in General Translation from University of Juba (2008). He awarded a bachelor degree in Sharia'a and Law in (2004) from Omdurman Islamic University. In addition to that he got an Intermediate Diploma in English Language from Nelain University in (2002) .He attended many courses and workshops in the field of English Language Teaching. He worked as an English teacher in Sudan Schools .He also worked as (ESP) Lecturer in Preparatory Year Program in several Saudi Universities. Currently he is (ESP) Lecturer at Posha Academy - Saudi Arabia - Riyadh City. He has published many research papers in different journals in the field of English Language Teaching and Translation.

Citation: Dr. Abdelrazig A bdelghani, Mahil Ibrahim. "Problem of Translating Metaphoric Expressions in the Holy Qur'an in to English." International Journal of Humanities Social Sciences and Education (IJHSSE), vol 4, no. 11, 2017, pp. 9-14. doi:http://dx.doi.org/10.20431/2349-0381.0411002.

Copyright: () 2017 Authors. This is an open-access article distributed under the terms of the Creative Commons Attribution License, which permits unrestricted use, distribution, and reproduction in any medium, provided the original author and source are credited. 